\title{
EFFECTS OF LAND USE ON SOIL QUALITY ON THE LOESS PLATEAU IN NORTH-WEST SHANXI PROVINCE
}

\author{
Qiang Zhang ${ }^{1,2,3, *}$, Li Wang ${ }^{2,3}$, Ruirui $\mathrm{Ji}^{2,3}$, Zhiping Yang ${ }^{2,3}$, Jianjie \\ Zhang 2,3 \\ ${ }^{1}$ Institute of Loess Plateau, Shanxi University, Taiyuan,Shanxi Province P. R. China 030031 \\ ${ }^{2}$ Institute of Soil and Fertilizer, Shanxi Academy of Agricultural Sciences, Taiyuan, Shanxi \\ Province P. R. China 030031 \\ 3 Shanxi Province key Laboratory of Soil Environment and Nutrient Resources Taiyuan, \\ Shanxi Province P. R. China 030031 \\ Corresponding author, Address: Institute of Soil and Fertilizer, Shanxi Academy of \\ Agricultural Sciences, Taiyuan, Shanxi Province P. R. China 030031 Tel: +86-351- \\ 7123127, Fax: +86-351-7123127,Email:sxsnkytfs@163.com
}

\begin{abstract}
Northwest Shanxi is located at the eastern border of the Loess Plateau. In order to guard against wind, to conserve water and soil, to fix sand, a large area of Caragana microphylla was planted in the hilly loess plateau in the north-west Shanxi province during the 1960s. To investigate how these measures affected soil properties and ultimately soil quality, a case study was conducted in Wuzhai (North-west Shanxi Province). Soil samples were collected from adjacent Caragana microphylla land, farm land, poplar forests, fallow land and mixed plantations of Caragana microphylla and poplar. Initially, soil properties under the five land-uses were studied separately. Then an evaluation indicator system was developed according to the principle of evaluation indicator selection. Subsequently, the method of multivariate analysis was used to carry through a complete scientific evaluation. Results showed a significant influence of land-use on soil properties. The value of SQI was the highest under the mixed plantation and, compared with the mixed plantation,the SQI of farmland decreased greatly. The SQI of fallow land was the lowest, but considering the soil nutrient content, land fallowing improved soil fertility to some extent. It was further shown that growing Caragana microphylla and mixed polar and Caragana microphylla plantation was the most sustainable ways of developing the loess plateau.
\end{abstract}

Keywords: $\quad$ Loess Plateau, Land use, Soil quality, Caragana microphylla

Please use the following format when citing this chapter:

Zhang, Q., Wang, L., Ji, R., Yang, Z. and Zhang, J., 2009, in IFIP International Federation for Information Processing, Volume 293, Computer and Computing Technologies in Agriculture II, Volume 1, eds. D. Li, Z. Chunjiang, (Boston: Springer), pp. 375-385. 


\section{INTRODUCTION}

The loess plateau is the energy and heavy chemical industry base and ecological barrier of eastern region and the frontier of ecological barriers. At present, the loss plateau is one of the areas of China where ecological degradation is most serious and the sustainable development ability is the lowest. The grave loss of soil and water, not only threaten the sustainable development of the loess plateau, but also the surrounding area even the whole nation directly.

Northwest Shanxi is located on the eastern border of the loess plateau.In order to guard against wind, to conserve water and soil, to fix sand and to develop animal husbandry, a large area of Caragana microphylla was planted in the hilly loess plateau in the north-west Shanxi province during the 1960s. Caragana microphylla has a developed rootstructure, is very hardy, and has considerable ability to conserve water and soil. However, to date, it is unknown whether these measures have been effective.

The aim of this research is to choose a representative site in north-west Shanxi Province, study soil properties and soil quality under different land uses in this area, and evaluate the existing ecology renewal measures.

\section{MATERIALS AND METHODS}

\subsection{Study sites}

The experiment was conducted in Wuzhai County $\left(38^{\circ} 44^{\prime} \sim 39^{\circ} 17^{\prime} \mathrm{N}\right.$ and $111^{\circ} 28^{\prime} \sim 112^{\circ} \mathrm{E}$ ), north-western Shanxi Province, in northern China. The county has a semi-arid climate. The average yearly temperature is $4.1^{\circ} \mathrm{C}-$ $5.5^{\circ} \mathrm{C}$, while the mean annual rainfall is $400 \mathrm{~mm}$. The altitude lies between $1200 \mathrm{~m}$ and $1400 \mathrm{~m}$.the soil is loam and the soil fertility is regarded as poor (Liu and Zhang, 1992).

\subsection{Soil sampling and analysis}

From April to November 2006, soil samples were collected from five land use types every month. Five adjacent land-uses with the same slope, having similar terrain factors, and used continuously for 30 years were selected: (1) farmland (buck wheat), (2) Caragana microphylla, (3) poplar, (4) mixed plantation of Caragana microphylla and poplar, (5) fallow land (fallowed for 3 years). Three typical sites were selected in each land type. All of the sites were located by GPS and flagged separately. At each site, three soil samples 
at each depth, $0-20 \mathrm{~cm}$ depth and $20-40 \mathrm{~cm}$ depth, were collected within a 100 $\mathrm{cm}$ radius.

Each sample weighed about $1 \mathrm{~kg}$ and samples from the same depth and the same site were bulked for analysis. Soil samples were analyzed for organic matters $(\mathrm{OM})$, total nitrogen (TN), available P (AP), available K (AK), total $\mathrm{K}(\mathrm{TK})$, and total $\mathrm{P}$ (TP), soil bulk density, $\mathrm{pH}$ and soil enzyme activity. Bulk density was determined by the core method. Soil $\mathrm{pH}$ was determined in 1:2.5 soil slurry, using a combination glass electrode. Soil OM was analyzed using the rapid dichromate oxidation techniques (Tiessen and Moir, 1993), TN was measured using the Kjeldahl technique (McGill and Figueiredo, 1993), and AP was extracted using the Olsen method (Olsen and Dean, 1965). AK was extracted with $1 \mathrm{~N}$ ammonium acetate, adjusted to $\mathrm{pH} 7$ (Simard, 1993), TP and TK were determined in a nitric-perchloric digestion extract, $\mathrm{P}$ by the method of Murphy and Riley (1962) and K by flame photometry.

\subsection{Evaluation method}

An evaluation indicator system, including physical indicators, chemical indicators and biological indicators was developed according to the principle of evaluation indicator selection. Following this, multivariate statistical analysis was used to carry through a complete scientific evaluation: according to membership function, realized the transaction of original data to the same dimension; as well as utilizing principle component analyzing solved how to determine the distribution of weightiness about every evaluated indicator.

We conducted one-way analyses of variance (ANOVAS) using SPSS software, with land use class as the main effect. The LSD procedure was used to separate the means of the soil properties at $\mathrm{p} \leq 0.05$. Principal component analysis was used to determine the distribution of weightiness about every evaluated indicator.

\section{RESULTS AND DISCUSSION}

\subsection{Effects of land use on soil physical, chemical and biological properties}

Soil under Caragana microphylla had the lowest bulk density, liquid percent,solid percent and the highest gas percent, and compared with other 
land uses, the difference was significant (Table 1). Soil of fallow land had the highest bulk density, $1.51 \mathrm{~g} / \mathrm{cm}^{3}$ and the lowest gas percent.

Tab.1 Effects of land use types on soil bulk density $(0 \sim 20 \mathrm{~cm})$

\begin{tabular}{lccccc}
\hline Land use & $\begin{array}{c}\text { Sampling depth } \\
(\mathrm{cm})\end{array}$ & $\begin{array}{c}\text { Bulk density } \\
(\mathrm{g} / \mathrm{cm} 3)\end{array}$ & $\begin{array}{c}\text { Liquid percent } \\
(\%)\end{array}$ & $\begin{array}{c}\text { Gas percent } \\
(\%)\end{array}$ & $\begin{array}{c}\text { Solid percent } \\
(\%)\end{array}$ \\
\hline Fallow land & $0 \sim 20$ & $1.51^{\mathrm{a}}$ & $16.2^{\mathrm{a}}$ & $22.37^{\mathrm{d}}$ & $61.43^{\mathrm{a}}$ \\
Farm land & $0 \sim 20$ & $1.33^{\mathrm{bc}}$ & $13.5^{\mathrm{b}}$ & $35.82^{\mathrm{b}}$ & $50.73^{\mathrm{c}}$ \\
Caragana microphylla & $0 \sim 20$ & $1.16^{\mathrm{d}}$ & $11.7^{\mathrm{d}}$ & $39.91^{\mathrm{a}}$ & $48.39^{\mathrm{c}}$ \\
$\begin{array}{l}\text { Mixed plantation of poplar and } \\
\quad \text { Cragana mcrophylla }\end{array}$ & $0 \sim 20$ & $1.29^{\mathrm{c}}$ & $12.4^{\mathrm{c}}$ & $37.76^{\mathrm{b}}$ & $49.89^{\mathrm{c}}$ \\
poplar & $0 \sim 20$ & $1.37^{\mathrm{b}}$ & $13.1^{\mathrm{b}}$ & $31.95^{\mathrm{c}}$ & $54.95^{\mathrm{b}}$ \\
\hline
\end{tabular}

Different letters above data represent statistically significant difference at $p<0.05$.

The root system of Caragana microphylla belongs to the axis-tiller type and has a strong penetration. During the root growth process, the soil is loosened leading to a decrease of bulk density and solid percent and an increase of gas percent (Niu et al., 2003). Consequently, soil density under Caragana microphylla was the lowest and, also because of the presence of roots of Caragana microphylla, the soil bulk density of the mixed plantation of Caragana microphylla and poplar was lower than that of poplar forest and this difference was significant. Due to human activity and animal tracking, fallow land had the highest soil bulk density.

Soil under the mixed plantation had the highest soil organic matters and total nitrogen (Table 2), most likely as a result of the abundant litter on the surface soil of the mixed plantation and the obvious humification of litter (Peng et al., 1996). Soil OM and TN under Caragana microphylla and poplar were lower than that under the mixed plantation, but higher than that under fallow land and farmland (Table 2). Soil under farmland had the lowest OM and TN (Table 2). This was because there were less residues accumulating on the surface of farmland, coupled with the impact of cultivation which enabled the rapid decomposition of the organic matter and the release of nitrogen. This nitrogen was available to, on one hand be absorbed and assimilated by the crops, but on the other hand be a major source of nitrate leaching (Peng et al., 1996). Higher soil OM content in shrub land compared with that in arbor land was also reported in a small catchment of the Loess Plateau (Gong et al., 2004).

The trend of AK content between the several land use types was similar to the trend of organic matter. The soil under poplar had the lowest AP content (Table 2). The AP under Caragana microphylla and the mixed plantation was higher than that under poplar, but lower than that under farmland (Table 2). The use of $P$ fertilizer may account for the highest AP content of soil in farmland. Because of the huge plant biomass, high absorption of soil nutrients and the obvious assimilation of available nutrients, AP and AK content under Caragana microphylla were lower relatively (Niu et al., 2003). Qiu et al. (2004), studying soil nutrients in different land uses in a small 
catchment of the Loess Plateau, reported soil in shrub land had the lowest AP content.

Tab.2 Effects of land use types on selected chemical properties $(0 \sim 20 \mathrm{~cm})$

\begin{tabular}{|c|c|c|c|c|c|c|c|c|}
\hline Land use & & $\begin{array}{c}\text { Organic matter } \\
(\mathrm{g} / \mathrm{kg})\end{array}$ & $\begin{array}{c}\text { Total-N } \\
(\mathrm{g} / \mathrm{kg})\end{array}$ & $\begin{array}{l}\text { Total-P } \\
(\mathrm{mg} / \mathrm{kg})\end{array}$ & $\begin{array}{l}\text { Total-K } \\
(\mathrm{mg} / \mathrm{kg})\end{array}$ & $\begin{array}{l}\text { Olsen-P } \\
(\mathrm{mg} / \mathrm{kg})\end{array}$ & $\begin{array}{c}\text { Available K } \\
(\mathrm{mg} / \mathrm{kg})\end{array}$ & $\mathrm{pH}$ \\
\hline \multirow{4}{*}{ Fallow land } & maximum & 6.378 & 0.848 & 536.43 & 2181.61 & 1.8689 & 72.00 & 8.59 \\
\hline & minimum & 5.918 & 0.478 & 460.44 & 1562.81 & 0.8379 & 59.50 & 8.51 \\
\hline & mean & 6.187 & 0.597 & 496.64 & 1815.49 & 1.5307 & 68.25 & 8.57 \\
\hline & C.V & 0.031 & 0.273 & 0.060 & 0.148 & 0.307 & 0.086 & 0.004 \\
\hline \multirow{4}{*}{ farmland } & maximum & 6.931 & 0.677 & 617.02 & 1935.40 & 4.1793 & 70.75 & 8.68 \\
\hline & minimum & 5.353 & 0.469 & 472.94 & 1506.35 & 1.9116 & 50.25 & 8.35 \\
\hline & mean & 5.889 & 0.581 & 509.09 & 1735.18 & 2.7699 & 62.90 & 8.49 \\
\hline & C.V & 0.113 & 0.172 & 0.119 & 0.093 & 0.444 & 0.121 & 0.016 \\
\hline \multirow{4}{*}{$\begin{array}{l}\text { Caragana } \\
\text { microphylla }\end{array}$} & maximum & 7.173 & 0.820 & 564.31 & 3572.06 & 1.9688 & 132.50 & 8.57 \\
\hline & minimum & 6.052 & 0.489 & 349.58 & 2426.31 & 1.0049 & 70.50 & 8.53 \\
\hline & mean & 6.450 & 0.624 & 461.72 & 3086.92 & 1.2644 & 97.80 & 8.55 \\
\hline & C.V & 0.072 & 0.196 & 0.189 & 0.152 & 0.372 & 0.246 & 0.002 \\
\hline \multirow{4}{*}{$\begin{array}{l}\text { Mixed } \\
\text { plantation of } \\
\text { poplar and } \\
\text { Caragana } \\
\text { microphylla }\end{array}$} & maximum & 9.061 & 0.149 & 502.52 & 3139.83 & 1.2197 & 172.50 & 8.60 \\
\hline & minimum & 7.072 & 0.520 & 388.35 & 1470.87 & 0.7667 & 77.00 & 8.49 \\
\hline & mean & 7.973 & 0.755 & 439.28 & 2222.50 & 1.0129 & 130.70 & 8.55 \\
\hline & C.V & 0.122 & 0.337 & 0.115 & 0.269 & 0.184 & 0.262 & 0.005 \\
\hline \multirow{4}{*}{ poplar } & maximum & 7.755 & 0.831 & 519.36 & 2664.61 & 0.8907 & 125.75 & 8.64 \\
\hline & minimum & 4.425 & 0.464 & 393.29 & 1382.40 & 0.3835 & 87.00 & 8.49 \\
\hline & mean & 6.378 & 0.611 & 429.36 & 2253.40 & 0.6247 & 107.15 & 8.57 \\
\hline & C.V & 0.237 & 0.264 & 0.123 & 0.222 & 0.365 & 0.149 & 0.008 \\
\hline
\end{tabular}

Catalase and alkaline phosphatase activity in the upper soil layer were significantly higher than that in the lower layer (Table 3). In contrast with the lower layer, the surface soil can more easily exchange matter and energy with atmosphere and the organic matter entering soil gathers first at the surface. Therefore, in the upper layer the nutrient conditions are better, activity of soil microbes is blooming and the enzyme activity is higher (An et al., 2004).

Tab.3 Effects of land use types on soil enzyme activity

\begin{tabular}{|c|c|c|c|c|}
\hline \multirow[t]{2}{*}{ Land use } & \multicolumn{2}{|c|}{$\begin{array}{c}\text { Catalase } \\
0.1 \mathrm{NKMnO}_{4} \mathrm{ml} / 100 \mathrm{~g} .37^{\circ} \mathrm{C} . \mathrm{d}^{-1} \\
\end{array}$} & \multicolumn{2}{|c|}{$\begin{array}{l}\text { Alkaline phosphatase } \\
\text { mg phenol } / 100 \mathrm{~g} .37^{\circ} \mathrm{C} \cdot \mathrm{d}^{-1}\end{array}$} \\
\hline & $0 \sim 20 \mathrm{~cm}$ & $20 \sim 40 \mathrm{~cm}$ & $0 \sim 20 \mathrm{~cm}$ & $20 \sim 40 \mathrm{~cm}$ \\
\hline Fallow land & $222.1^{\mathrm{b}}$ & $143.5^{\mathrm{c}}$ & $1214.8^{\mathrm{bc}}$ & $918.3^{\mathrm{b}}$ \\
\hline Farm land & $288.4^{\mathrm{a}}$ & $203.2^{\mathrm{b}}$ & $1185.1^{\mathrm{c}}$ & $919.6^{\mathrm{b}}$ \\
\hline Caragana microphylla & $267.3^{\mathrm{a}}$ & $214.3^{\mathrm{b}}$ & $1458.4^{\mathrm{a}}$ & $902.6^{\mathrm{c}}$ \\
\hline $\begin{array}{l}\text { Mixed plantation of poplar and Caragana } \\
\text { microphylla }\end{array}$ & $277.0^{\mathrm{a}}$ & $255.2^{\mathrm{a}}$ & $1250.2^{\mathrm{b}}$ & $948.5^{\mathrm{a}}$ \\
\hline poplar & $270.5^{\mathrm{a}}$ & $242.9^{\mathrm{a}}$ & $1227.3^{\mathrm{b}}$ & $924.7^{\mathrm{b}}$ \\
\hline
\end{tabular}

Different letters above data represent statistically significant difference at $p<0.05$.

The top $20 \mathrm{~cm}$ soil under Caragana microphylla had the highest soil alkaline phosphatase activity and there were significant differences between soil under Caragana microphylla and that under several other land use types (Table 3). The impact of Caragana microphylla roots and the decomposition and mineralization of litter improve soil physical condition and increase soil organic matter content. Good soil physical conditions and the high soil organic matter content induce an increase of diversity and number of soil microbes (Niu et al., 2003). This would have accounted for the higher alkaline phosphatase activity under Caragana microphylla and the mixed 
plantation. There were no significant differences of catalase activity among the five land use types, but the catalase activity of fallow land was the lowest (Table 3).

\subsection{Calculation of soil quality}

We mainly considered soil fertility quality when the evaluation indicators were selected.The evaluated indicators were: $\mathrm{X} 1-\mathrm{OM} 、 \mathrm{x} 2-\mathrm{TN} 、 \mathrm{x} 3-$ TP $、 \mathrm{x} 4-\mathrm{TK} 、 \mathrm{x} 5-\mathrm{AP} 、 \mathrm{x} 6-\mathrm{AK} 、 \mathrm{x} 7-\mathrm{pH} 、 \mathrm{x} 8$ - Bulk density $\mathrm{x} 9-$ total porosity $\mathrm{x} 10$ - alkaline phosphatase $\mathrm{x} 11$ - catalase.

\subsubsection{Membership functions for different evaluation indicators}

There is no clear extension, nor uniform dimension among different evaluation indicators, so the values measured can not be used in soil quality evaluation directly. We should apply normalized transaction. First of all, we must select membership functions for the different evaluation indicators.

\section{(a) Ascending half trapezoidal membership function.}

Within a certain range, some indicators are positively correlated with soil quality (such as soil fertility status, soil health, etc), and there is little influence on soil quality whether the indicator is under the lower limit or above the upper limit. The membership function of these indicators can be approximated to the distribution of an ascending half trapezoid (Fig. 1). Its membership function model is as follows:

$$
\mu(x)= \begin{cases}1 & \left(x \geq x_{0}\right) \\ x / x_{0} & \left(x<x_{0}\right)\end{cases}
$$

where $x$ is the actual value of evaluated indicators, $x_{0}$ the upper limit and $\mu$ $(x)$ is the membership function of $\mathrm{x}$.

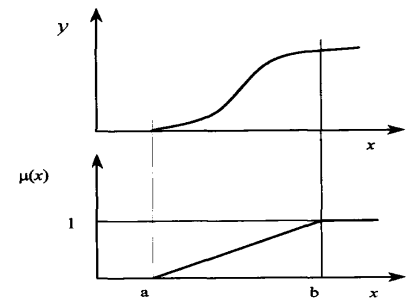

Fig. 1 Distribution of "S" curve and trapezoid ascending half trapezoid

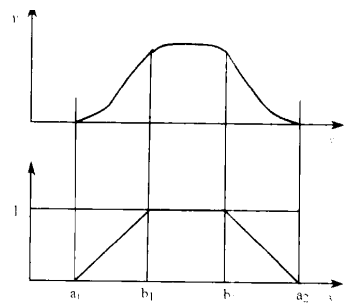

Fig. 2 Distribution of parabola and

\section{(b) Triangular membership function}

There is an optimum range when soil $\mathrm{pH}$ and bulk density influence the soil function. Within this range, the soil function is optimal. Over the range, 
the bigger the deviation, the worse is the soil function. These indicators can be considered as a trapezoidal distribution (Fig.2). To simplify, we replaced optimum range with an optimum value; here the trapezoidal function is simplified to a triangular function (Fig. 3).

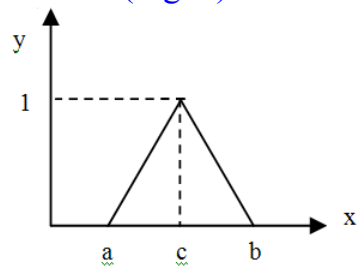

Fig. 3 Distribution of triangle

$$
\mu(x)= \begin{cases}0 & (x \leq a \text { 或 } x \geq b) \\ \frac{x-a}{c-a} & (a<x<c) \\ \frac{b-x}{b-c} & (c<x<b) \\ 1 & (x=c)\end{cases}
$$

Where $x$ is the actual value of the evaluation indicator, $b$ is the upper limit value, $a$ is the lower limit value, $c$ is the optimum value of the evaluation indicator and $\mu(x)$ is the membership function of $x$.

Secondly, we ascertained the limit value of the indicators according to the actual value measured in this study area (Table 4).

Then, according to the limit value of the evaluation indicators, the membership values were calculated (Table 5, Table 6).

Tab.4 Limit values of evaluated indicators

\begin{tabular}{|c|c|c|c|c|c|c|}
\hline \multirow{2}{*}{ Indicator } & \multicolumn{2}{|c|}{ Upper limit } & \multicolumn{2}{|c|}{ Medium limit } & \multicolumn{2}{|c|}{ Lower limit } \\
\hline & value & membership & value & membership & value & membership \\
\hline Bulk density $/ \mathrm{g} / \mathrm{cm}^{3}$ & 1.8 & 0 & 1.1 & 1 & 0.9 & 0 \\
\hline Total porosity /\% & 51.61 & 1 & - & - & 0 & 0 \\
\hline $\mathrm{pH}$ & 9.5 & 0 & 8.5 & 1 & 7 & 0 \\
\hline $\mathrm{AP} / \mathrm{mg} / \mathrm{kg}$ & 2.7699 & 1 & - & - & 0 & 0 \\
\hline $\mathrm{AK} / \mathrm{mg} / \mathrm{kg}$ & 130.7 & 1 & - & - & 0 & 0 \\
\hline $\mathrm{TN} / \mathrm{g} \cdot \mathrm{kg}^{-1}$ & 0.755 & 1 & - & - & 0 & 0 \\
\hline $\mathrm{TP} / \mathrm{mg} / \mathrm{kg}$ & 509.09 & 1 & - & - & 0 & 0 \\
\hline $\mathrm{TK} / \mathrm{mg} / \mathrm{kg}$ & 3086.92 & 1 & - & - & 0 & 0 \\
\hline $\mathrm{OM} / \mathrm{g} \cdot \mathrm{kg}^{-1}$ & 7.973 & 1 & - & - & 0 & 0 \\
\hline $\begin{array}{l}\text { Alkaline phosphatase } / \mathrm{mg} \\
\text { phenol } / 100 \mathrm{~g} .37^{\circ} \mathrm{C} \cdot \mathrm{d}^{-1}\end{array}$ & 1458.4 & 1 & - & - & 0 & 0 \\
\hline $\begin{array}{l}\text { Catalase } / 0.1 \mathrm{NKMnO}_{4} \mathrm{ml} / 100 \\
\text { g. } 37^{\circ} \mathrm{C} \cdot \mathrm{d}^{-1}\end{array}$ & 288.4 & 1 & - & - & 0 & 0 \\
\hline
\end{tabular}

Tab.5 Membership function values of evaluated indicators

\begin{tabular}{lcccccc}
\hline Land use & $O M$ & $T N$ & $T P$ & $T K$ & $A P$ & AK \\
\hline Fallow land & 0.776 & 0.791 & 0.976 & 0.588 & 0.553 & 0.522 \\
farmland & 0.739 & 0.770 & 1.000 & 0.562 & 1.000 & 0.481 \\
Caragana microphylla & 0.809 & 0.826 & 0.907 & 1.000 & 0.456 & 0.748 \\
Mixed plantation of poplar & 1.000 & 1.000 & 0.863 & 0.720 & 0.366 & 1.000 \\
and Caragana microphylla & 0.800 & 0.809 & 0.843 & 0.730 & 0.226 & 0.820 \\
poplar & & & & & &
\end{tabular}


Tab.6 Membership function values of evaluated indicators

\begin{tabular}{lccccc}
\hline Land use & $\mathrm{pH}$ & Bulk density & Total porosity & Alkaline phosphatase & catalase \\
\hline Fallow land & 0.930 & 0.414 & 0.747 & 0.833 & 0.770 \\
farmland & 1.000 & 0.671 & 0.955 & 0.813 & 1.000 \\
Caragana microphylla & 0.950 & 0.914 & 1.000 & 1.000 & 0.927 \\
Mixed plantation of poplar & 0.950 & 0.729 & 0.971 & 0.857 & 0.960 \\
and Caragana microphylla & 0.930 & 0.614 & 0.873 & 0.842 & 0.938 \\
poplar & & & &
\end{tabular}

\subsubsection{Determining the weightiness of evaluated indicators}

In this paper we utilize principal component analysis to determine the weightiness of evaluated indicators.If the Eigen values of the principal component is greater than 1 and the cumulative contribution rate is $85 \%$ or greater than $85 \%$, the principal component can be extracted.

Tab.7 Total Variance Explained

\begin{tabular}{ccccccc}
\hline \multirow{2}{*}{ Component } & \multicolumn{3}{c}{ Initial Eigenvalues } & \multicolumn{2}{c}{ Extraction Sums of Squared Loadings } \\
\cline { 2 - 6 } & Total & \% of Variance & Cumulative \% & Total & \% of Variance & Cumulative \% \\
\hline 1 & 5.233 & 47.576 & 47.576 & 5.233 & 47.576 & 47.576 \\
2 & 3.190 & 29.003 & 76.580 & 3.190 & 29.003 & 76.580 \\
3 & 1.910 & 17.367 & 93.947 & 1.910 & 17.367 & 93.947 \\
4 & .666 & 6.053 & 100.000 & & & \\
5 & $8.536 \mathrm{E}-16$ & $7.760 \mathrm{E}-15$ & 100.000 & & \\
6 & $4.504 \mathrm{E}-16$ & $4.095 \mathrm{E}-15$ & 100.000 & & \\
7 & $1.712 \mathrm{E}-16$ & $1.557 \mathrm{E}-15$ & 100.000 & & \\
8 & $-1.010 \mathrm{E}-16$ & $-9.183 \mathrm{E}-16$ & 100.000 & & & \\
9 & $-2.283 \mathrm{E}-16$ & $-2.076 \mathrm{E}-15$ & 100.000 & & & \\
10 & $-3.050 \mathrm{E}-16$ & $-2.773 \mathrm{E}-15$ & 100.000 & & & \\
11 & $-6.928 \mathrm{E}-16$ & $-6.298 \mathrm{E}-15$ & 100.000 & & & \\
\hline
\end{tabular}

Extraction Method: Principal Component Analysis.

Tab.8 Component Matrix

\begin{tabular}{lccc}
\hline & \multicolumn{3}{c}{ Component } \\
\cline { 2 - 4 } & 1 & 2 & 3 \\
\hline OM x1 & 0.762 & -0.209 & 0.514 \\
TN x2 & 0.751 & -0.150 & 0.534 \\
TP x3 & -0.850 & 0.347 & $-7.009 \mathrm{E}-02$ \\
TK x4 & 0.747 & 0.178 & -0.639 \\
AP x5 & -0.697 & 0.664 & 0.158 \\
AK x6 & 0.935 & -0.221 & 0.266 \\
pH x7 & -0.307 & 0.895 & 0.322 \\
Bulk density x8 & 0.699 & 0.669 & -0.252 \\
Total porosity x9 & 0.618 & 0.783 & $7.569 \mathrm{E}-02$ \\
Alkaline phosphatase x10 & 0.587 & 0.253 & -0.730 \\
catalase x11 & 0.374 & 0.747 & 0.382 \\
\hline
\end{tabular}

Extraction Method: Principal Component Analysis.

In Table 7, the cumulative contribution rate of the first three components is $93.947 \%$. From this we can also see that the three components can almost 
reflect the information of all of the indicators. We can thus replace the 11 components with the first three components.

Dividing the data in Table 8 by the square root of eigenvalues, we can get the corresponding coefficient of the indicators in the first three principal components. The three principal components are as follows:

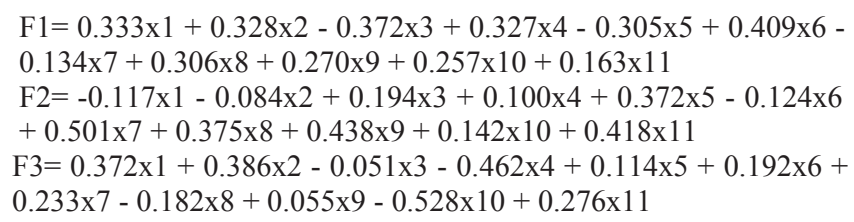

The overall score model is calculated as follows:

$\mathrm{Y}=\mathrm{F} 1 * 47.576 \% / 93.947+\mathrm{F} 2 * 29.003 \% / 93.947+\mathrm{F} 1 * 17.367 \% / 93.947$

The overall score model is:

$\mathrm{Y}=0.201 \mathrm{X} 1+0.212 \mathrm{X} 2-0.138 \mathrm{X} 3+0.111 \mathrm{X} 4-0.019 \mathrm{X} 5+0.204 \times 6$

$+0.130 \times 7+0.237 \times 8+0.282 \times 9+0.076 \times 10+0.263 \times 11$

In this model, the coefficient of every component is the weightiness of every indicator.

\subsubsection{Calculating soil quality index}

The soil quality index was calculated as follows:

$$
S Q I=\sum_{i=1}^{n} K_{i} \times C_{i}
$$

Where $S Q I$ is soil quality index, $\mathrm{Ci}$ is the membership function value of indicators, $K i$ is the weightiness of indicators and $n$ is the number of evaluated indicators.

The values of the soil quality index of Caragana microphylla, farmland, poplar, fallow land and the mixed plantation of Caragana microphylla and poplar were 1.410, 1.199, 1.284, 1.046, and 1.459, respectively (Fig. 4).

Compared with Caragana microphylla and the mixed plantation of Caragana microphylla and poplar, the value of the soil quality index of farm land was greatly reduced (Fig. 4), indicating that the soil degraded. Cultivation practices increased bulk density, and decreased enzyme activity, soil total nitrogen and organic matter content in soil. Although a lot of fertilizers including some available nutrients, e.g. Olsen P, were applied to the cropland, the soil quality could not be improved greatly. Application of fertilizer could only improve the contents of available nutrients.

The value of the soil quality index of fallow land was the lowest. In contrast with farmland, leaving land fallow could improve total nitrogen, total $\mathrm{K}$, and organic matter content in soil. However, the comprehensive soil 
quality of fallow land was lower than that of farmland. Analyzing and comparing every soil properties, we can see that the soil under fallow land had higher bulk density and lower total porosity than that of farmland.

It was further shown that growing Caragana microphylla and the mixed plantation of Caragana microphylla and poplar were the most sustainable ways of developing the Loess Plateau.

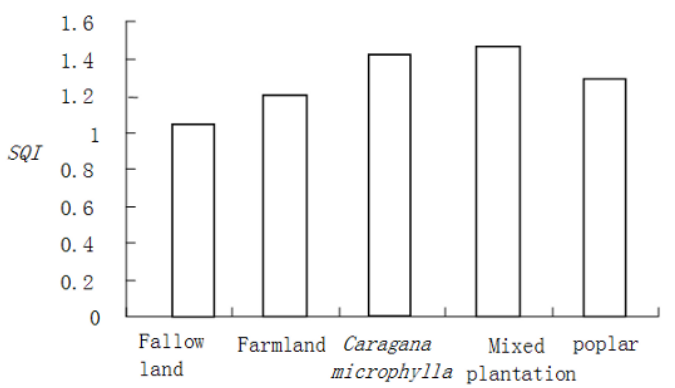

Fig4. Soil quality index values under different land use types

\section{CONCLUSIONS}

Plantations of Caragana microphylla and mixed plantations of Caragana microphylla and poplar can improve soil physical character, enzyme activity, and total nitrogen and organic matter content. The SQI of mixed plantations of Caragana microphylla and poplar was the highest of all and that of Caragana microphylla was the second highest. It was further shown that growing Caragana microphylla and the mixed plantation of Caragana microphylla and poplar provided the most sustainable ways of developing the Loess Plateau. Cropland soil was degraded, since cultivation practice increased bulk density, and decreased enzyme activity, soil total nitrogen and organic matter content in the soil. In contrast with farmland, land fallowing could improve total nitrogen, total $\mathrm{K}$, and organic matter content in the soil. Considering the soil nutrient contents, land fallowing improved soil fertility to some extent.

\section{REFERENCES}

An, S.S., Huang, Y.M., Li, B.C., Ji, w.j., Zou, H.Y., 2004. Characteristics of soil enzymatic activities in enclosed area of Yunwu Mountain. Bulletion of Soil and Water Conservation, 24(6): $14 \sim 18$

An, S.S., Huang, Y.M., Liu, M.Y., Li, B.C., 2005. The responses and evaluation of soil enzymatic activities to plant rehabilitation in Ningxia Loess Hilly-gully Region. Research of Soil and Water Conservation,12(3) :31 34. 
Feng, X.P., 2006. Discussion about the ecological recovery of the Loess Plateau. Soil and Water Conservation Science and Technology in Shanxi, 4: 26 27.

Gong, J., Chen, L.D., Fu, B.J., Hu, C.X., Wei, w., 2004. Effects of land use and vegetation restoration on soil quality in a small catchment of the Loess Plateau. Chinese Journal of Applied Ecology, 15(12): 292 2296.

Liu, Y.Z., Zhang, J.Y., 1992. Shanxi Soil. Science publisher, Beijing

McGill, W.B., Figueiredo, C.T., 1993. Total nitrogen. In: Cater, M.R. (Ed.), Soil Sampling and Methods of Analysis. Lewis Publishers, Boca Raton, FL, pp. 201 211

Murphy, J., Riley, J.P., 1962. A modified single solution method for determination of phosphate in natural waters. Anal. Chim. Acta, 27, 31 36

Niu, X.W., 2003. Research of Caragana microphylla. Science publisher, Beijing, 3 25

Niu, X.W., Zhang, Q., Yang, Z.P., Cheng, B., Shi, Q.L., 2003. Research on change of soil properties of Caragana plantation in north-west of Shanxi Province. Acta Bot. Boreal.Occident. Sin. 23(4): 628 632

Olsen, S.R., Dean, L.A., 1965. Phosphorus. In: Black, C.B. (Ed.), Methods of Soil Analysis. Part 2. Chemical and Microbiological Properties. American Society of Agronomy, Madision, WI, pp. 1035 1049

Peng, L., Wang, J.Z., Yu, C.Z., 1996. Soil nitrogen uptake by crops, nitrogen leaching and Loss from the Eroded dryland. Journal of Soil and Water Conservation, 2(2): 9 16

Qiu, Y., Fu, B.J., Wang, J., Chen, L.D., 2004. Variance and influence factors of soil nutrient in a small catchment in hilly Loess area. Progress in Natural Science, 14(3), 294 299

Simard, R.R., 1993. Ammonium acetate-extractable elements. In: Cater, M.R. (Ed.), Soil Sampling and Methods of Analysis. Lewis Publishers, Boca Raton, FL, pp: 39 42

Sun, B., Zhao, Q.G., 1999. Evaluation indexes and methods of soil quality concerning red soil degradation. Progress in Geography, 18(2):118 128

Tiessen, H., Moir, J.O., 1993. Total and organic carbon. In: Cater, M.R. (Ed.), Soil Sampling and Methods of Analysis. Lewis Publishers, Boca Raton, FL, pp. 187 199 